Основная цель этого контроля - распределение индивидов в соответствии с их талантами и возможностями успешного выполнения своих социальных функций. Поэтому образование наряду с другими социальными институтами, такими, как семья, церковь, политические, профессиональные организации и другими является одновременно каналом вертикальной циркуляции, способствующим продвижению вверх или спуску вниз по социальной лестнице и своеобразным «ситом», которое «просеивает» индивидов и определяет им то или иное место в обществе.

Таким образом, влияние высшего образования на формирование индивидом той или иной жизненной стратегии достаточно большое, т.е. высшее образование в этой связи должно рассматриваться как один из важнейших факторов еe выбора. Действительно, основным компонентом, базисом жизненной стратегии в рамках представленного исследования являются ценностные ориентации индивида. Ведь именно исходя из них, все мы строим свои планы, расставляем приоритеты, формулируем себе цели и продумываем пути их достижения. А на систему ценностей огромное влияние наряду с семейным воспитанием и ближайшим окружением оказывает образование человека, т.к. во многом благодаря ему люди расширяют свой кругозор, открывают что-то новое в себе самих, осознают свои потребности и стремления, задумываются о смысле жизни и о своем месте в ней, видят новые горизонты или же новые пути к достижению ранее поставленных целей.

$$
* * *
$$

1. Васильева О. С., Демченко Е. А. Изучение основных характеристик жизненной стратегии человека / Вопросы психологии. 2002, № $4 .-74$ с.

2. Головаха Е. И. Жизненная перспектива и ценностные ориентации личности / Психология личности в трудах отечественных психологов. СПб., 2000. - 266-267 с.

3. Лунина Ю. В. Жизненные стратегии молодежи: основные направления социальной поддержки. / Вестник Оренбургского государственного университета. 2008, № 1. - 36 с.

4. Медведев А. М. Особенности формирования жизненной стратегии современной молодежи. / Мир современной науки. 2011, № 4. -4 с.

5. Осипова Л. Б., Энвери Л. А. Жизненные стратегии современной молодежи. / Вестник Вятского государственного гуманитарного университета. 2012, № 4 / том 4. - 106-107 с.

6. Осипова Л. Б. Роль семьи в выборе жизненной траектории молодежью. URL: http://www.scienceeducation.ru/pdf/2015/2-2/411.pdf

7. Садыков Р. М. Занятость молодежи в сельской местности: проблемы и пути решения. / Вестник Башкирского университета. 2011, № 1 / том 16. - 219 с.

8. Сушко В. А. Высшее образование как фактор влияния на выбор жизненной стратегии современной молодежи. / Экономика, социология и право, 2016. - 92 с.

9. Фрейджер Р., Фейдимен Д. Личность: теории, упражнения, эксперименты. СПб.: Прайм Еврознак, 2008. - $126 \mathrm{c}$.

10. Хижкина Н. А. Влияние семьи на формирование ценностных ориентаций подростков. / Вестник Тамбовского университета. Серия: Гуманитарные науки. 2007, № 10. - 142 с.

11. Черкасова М. А. Современные жизненные стратегии и их роль в успешной самореализации учащиеся молодежи. / Вестник Северо-Кавказского гуманитарного института. 2014, № 3 (11). - 124 с.но на Allbest.ru

\title{
Кислова Е.В. \\ Соучастие в преступлении и проблемы установления его признаков
}

Российский государственный соџиальный университет

(Россия, Москва)

doi:10.18411/spc-20-12-2017-03

idsp: 000001:spc-20-12-2017-03

Теоретическая модель института соучастия в преступлении имеет два текстовых уровня: поверхностный (конструктивный) и глубинный (концептуальный). Наличие двух уровней в нормативном тексте института соучастия обусловливает необходимость рассмотрения конструктивных особенностей института соучастия, его уголовно- 
правовых предписаний, а также концептуальных построений, которые нашли свое закрепление в нормативном тексте. Поверхностный и концептуальный уровни законодательного текста взаимосвязаны между собой: с одной стороны, концептуальная основа нормативного текста определяет особенности законодательнотекстологического конструирования уголовно-правовых предписаний и института соучастия в целом, с другой стороны, конструктивные элементы соответствующего текста (их набор, последовательность и функциональная нагрузка), в свою очередь, определяют возможности глубинной интерпретации и в конечном итоге особенности применения уголовно-правовых предписаний института соучастия.

Уголовно-правовые предписания, образующие институт соучастия, базируются на теории комбинированной ответственности соучастия, которая включает в себя концепцию акцессорной природы соучастия и концепцию индивидуальной (самостоятельной) ответственности соучастников преступления. Концепция акцессорной природы соучастия разработана представителями классической школы уголовного права и воспринята значительной частью российских ученых. В немецком уголовном праве эта концепция известна как "теория производной ответственности", в русском уголовном праве - как концепция "солидарной ответственности всех соучастников", а также как "теория акцессорной природы соучастия". Впервые свое законодательное воплощение общая теория соучастия, основанная на принципе акцессорности, получила в Уголовном кодексе Франции 1791 г., а затем в Кодексе Наполеона 1810 г. В указанных законодательных актах уголовно-правовая оценка преступлений, совершенных соучастниками, полностью зависела от квалификации деяния, совершенного исполнителем. Согласно акцессорной природе соучастия в уголовном праве воплощается правило: accessorium sequitur prinsipale (второстепенное следует за главным). Концепция акцессорности включает в себя три основных положения:

1) главной фигурой соучастия является исполнитель преступления;

2) без исполнителя соучастие в преступлении не существует;

3) ответственность других участников преступления зависит от того, какое деяние в рамках общего умысла совершает исполнитель (приготовление, покушение, оконченное преступление).

Законодательно-текстологический подход предполагает рассмотрение законодательных и доктринальных концептов, составляющих понятийный аппарат института соучастия и учения о соучастии в преступлении. Законодательными концептами института соучастия являются используемые законодателем ментальные единицы, имеющие уголовно-правовое значение: "соучастие в преступлении", "соучастники преступления", "исполнитель", "организатор", "подстрекатель", "пособник", "группа лиц", "группа лиц по предварительному сговору", "организованная группа", "преступное сообщество (преступная организация)", "эксцесс исполнителя преступления" и другие уголовно-правовые образования, включенные в нормативный текст. Количество законодательных концептов ограничено рамками нормативного текста. Ключевые законодательные концепты используются в качестве заголовков, например "Соучастие в преступлении" (глава 7), либо в структуре заголовков - ст.32 "Понятие соучастия в преступлении", а также в уголовно-правовых предписаниях в качестве конструктивных элементов. Например, концепт "исполнитель преступления" фигурирует в ч. 1, 2 ст. 33 и в ст. 36 УК РФ (дважды), итого - шесть раз, не считая заголовка ст. 36 УК РФ.

В отдельных случаях законодательные концепты могут не иметь терминологического обозначения. В институте соучастия таким концептом является "неудавшееся подстрекательство", его содержание выражено в уголовно-правовом предписании, сформулированном в ч. 5 ст. 35 УК РФ, где речь идет об уголовной ответственности лица, которому "по не зависящим от него обстоятельствам не удалось склонить других лиц к совершению преступления". Равным образом в действующем УК РФ концепт "ответственность организаторов и участников организованной 
преступной группы или преступного сообщества" складывается из содержания ч. 4, 5, 6 ст. 35 УК РФ. Есть основание считать, что законодательный концепт как мысленный образ объекта, имеющего уголовно-правовое значение, формируется постепенно и находит свое выражение сначала в нормативном тексте, затем в его заголовке и, наконец, получает терминологическое обозначение в тексте статьи. При этом в эпоху законописания, когда законодательство опережает теорию, нормативные концепты заимствуются из обычного права. В эпоху законотворчества, когда теория опережает либо сопровождает законодательную деятельность, доктринальные концепты предшествуют либо сопровождают концепты, используемые законодателем. Так, в Уголовном уложении 1903 г., согласно ст. 51, "...соучастниками признаются те, которые... 2) подстрекнули другого к соучастию в преступном деянии...". Уложению не известен концепт "неудавшееся подстрекательство". Однако теория оперирует этим концептом, выделяя "два рода случаев:

1) когда подстрекнутый не совершает никакого действия, потому что у него не образовалось решимости совершить преступление;

2) когда решимость у подстрекнутого сложилась самостоятельно, помимо влияния подстрекателя". В Уложении 1903 г. отсутствует и указание на эксцесс исполнителя. В то же время в литературе подробно рассматривается "эксцесс подстрекнутого" и выделяются три вида такого эксцесса. В действующем Уголовном кодексе РФ концепт "эксцесс подстрекнутого" получает терминологическое обозначение в несколько измененном виде в ст. 36 УК РФ об эксцессе исполнителя преступления.

В этой связи доктринальные концепты, в отличие от законодательных, не поддаются строгому учету. Вместе с тем их можно классифицировать для нужд уголовного права по различным основаниям:

1) по источнику - на теоретические и модельные;

2) по степени распространенности - на общепризнанные и единичные;

3) по качеству - на корректные и недостаточно корректные и т.д.

В современной уголовно-правовой литературе количество новых доктринальных концептов, имеющих отношение к институту соучастия, сравнительно невелико, т.к. большинство уголовно-правовых явлений концептуализировано в процессе теоретических исследований, законопроектной деятельности и толкования уголовноправовых предписаний. Новые термины, которые обозначают уголовно-правовые явления, зачастую не выходят за рамки хорошо известных концептов, таковы, например, термины "субъект уголовной ответственности", "третьи лица, используемые для совершения преступления", "лицо, содействовавшее совершению преступления", которыми обозначены законодательные концепты "субъект преступления" (ч. 4 ст. 34 УК), "лицо, совершившее преступление посредством использования других лиц" (ч. 2 ст. 33 УК), "пособник" (ч. 5 ст. 33 УК)

$$
\text { *** }
$$

1. "Уголовный кодекс Российской Федерации" от 13.06.1996 № 63-ФЗ(ред. от 29.07.2017) ( с изм. и доп., вступ. в силу с 26.08.2017)

2. Абакууменко С.Е. - Понятие соучастия в преступлении // Современные подходы к управлению социально-экономическими и политическими процессами. Сборник научных трудов. - Саратов: Изд-во Поволж. акад. гос. службы, 2004. - С. 78-80

3. Аверкин С.Д. - Значение субъектвных признаков соучастия в преступлении //Уголовное судопроизводство: проблемы теории, нормотворчества и правоприменения. Сборник научных трудов. - Рязань: Академия права и управления Федеральной службы исполнения наказаний, 2006, Вып.1 - С. 208 - 214.

4. Андреев А.Г., Заболоцкая А.Г., Хоршева В.С.. Проблемы определения признаков соучастия // Современные проблемы противодействия преступности: материалы всероссийской научнопрактической конференции (22 - 23 июня 2010 г., г.Волгоград). - Волгоград: ВА МВД России, 2010. - C. $116-121$

5. Балеев С.А. - Форма соучастия в преступлении: понятие и классификация // Ученые записки Казанского государственного университета. - Казань: Изд-во Каз. гос. ун-та, 2010, Т. 152, Кн.4. - С. $154-159$ 